\title{
レチノマックス ${ }^{\circledR} て ゙$ 測定した 3 歳児の屈折值 ( 3 歳児健診での測定結果から)
}

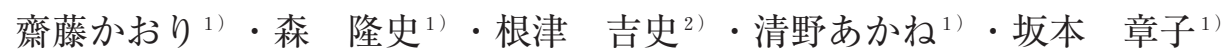

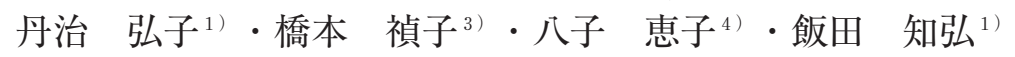

\footnotetext{
1) 福島県立医科大学眼科学講座

2) 福島県立南会津病院

3) 桜水さかい眼科

4) 仁泉会 北福島医療センター
}

\section{Refraction of three-year-old children measured by Retinomax ${ }^{\circledR}$ (Result of three-year-old health checkup)}

\author{
Kaori Saito ${ }^{1)}$, Takafumi Mori ${ }^{1)}$, Yoshifumi Netsu ${ }^{2)}$, Akane Seino ${ }^{1)}$ \\ Akiko Sakamoto $^{1)}$, Hiroko Tanji ${ }^{1)}$, Teiko Hashimoto ${ }^{3)}$ \\ Keiko Yago $^{4)}$ and Tomohiro Iida ${ }^{1)}$ \\ 1) Department of Ophthalmology, Fukushima Medical University \\ ${ }^{2)}$ Minamiaizu Prefectural Hospital \\ 3) Sakuramizu Sakai Eye Clinic \\ 4) Northern Fukushima Medical Center
}

別冊請求先（テ960-1295）福島県福島市光が丘1番地 福島県立医科大学眼科学講座

$$
\begin{aligned}
& \text { Tel. (024) 547-1303 Fax. (024) 548-2640 } \\
& \text { E-mail tanji@beach.ocn.ne.jp }
\end{aligned}
$$

Key words：3 歳览健康診查、屈折率測定、遠視、乱視、不同視

Health checkup program for children of three years of age, Refractometry, Hyperopia, Astigmatism, Anisometropia 
目的：3 歳児の携帯型自動屈折検查機での屈折值を報告し、それを 3 歳児健診で用いる際の方法と 留意点について考案する。

対象と方法：福島市の 3 歳児健診には、毎回 2 名の視能訓練士が参加し、全受診児に対して屈折値 を測定している。平成15年度から 18 年度に福島市の 3 歳児健診を受診し、両眼の屈折值が測定でき た10,454人、20,908眼を対象とし、レチノマックスによる自然瞳孔下の屈折值を収集し統計学的に 検討した。

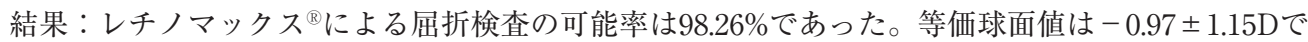
あったが、最頻值は-0.875D、丕度はー0.64で遠視側により急峻、近視側により平坦な分布であっ

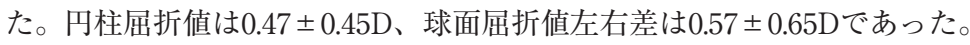

結論：3 歳児健診でのレチノマックス ${ }^{\circledR}$ 屈折検查は、検查可能率が高く、健診現場での使用には有 用である。しかし、調節の介入があることから、それのみで視力に代わるスクリーニング検查には なりえない。視力值と照合して結果を判断すれば、補助的に効果を発揮すると考えた。

\section{Abstract}

Purpose: To evaluate the refraction measured by portable autorefractometer at three years old of general population and to devise directions and considerations for use in three-year-old health checkup.

Subjects and Methods: Two orthoptists participate in three-year-old health checkup of Fukushima city every time and measure refraction for all consultation child by Retinomax ${ }^{\oplus}$ without cycloplegia. Subjects were 20,908 eyes of 10,454 children who had measurement of refraction at three-year-old health checkup of Fukushima city from the year 2003 to 2006. We collected refraction value and analyzed all data statistically.

Results: The refraction test by Retinomax ${ }^{\circledR}$ was possible in $98.26 \%$ of three years old children. The mean spherical equivalent value was $-0.97 \pm 1.15 \mathrm{D}$, the mode was $-0.87 \mathrm{D}$, the skewness was -0.64 and the distribution was flat in the myopia side and steep in the hyperopia side. The mean cylindrical power was $0.47 \pm 0.45 \mathrm{D}$ and the mean difference of spherical power in two eyes was $0.57 \pm 0.65 \mathrm{D}$.

Conclusion: The refraction test by Retinomax ${ }^{\circledR}$ is useful in three-year-old health checkup because of high possibility rate of the examination. However, it cannot be used as the screening examination in place of visual acuity test, because accommodation always affects the result of the refraction. We consider that refraction test can play a supporting role if we collate it with their visual acuity and judge a result.

\section{I. 緒言}

3 歳児健診での視力測定や問診のみでは見逃 されやすい弱視や屈折異常の発見には、視力検 查に併せて屈折検査を行うことが有用と報告さ

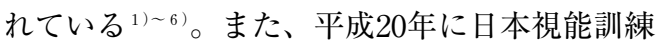
士協会から発表された「三歳児眼科健診マニュ アル」でも精度の高い健診には屈折検査が重要 とされているが7)、屈折検査が導入されている
自治体は $5.2 \%$ と少ない ${ }^{8)}$ 上、自治体によって検 査内容に差がある ${ }^{9)}$ 。

近年では大規模な市町村合併などで健診の現 場が変化していることから、今後、健診に屈折 検查が導入される自治体が増加することが期待 される。しかし、検査機器の種類により測定值 に差があると予測され、使用する機種による 3 歳児の屈折分布を知ることが必要である。福島 市では、 3 歳児健診受診児全てにニコン社製手 
持ち式オートレフラクトメーター（レチノマッ クス $\left.{ }^{\circledR}\right)$ による屈折検査を行っているが、今回、 その検査結果を統計学的に検討するとともに、 本機器を 3 歳児健診で用いることの有用性と問 題点を検討したので報告する。

\section{II. 対象及び方法}

15年度から 18 年度に福島市の 3 歳児健診を受 診し、両眼の屈折值が測定できた 10,454 人、 20,908 眼の、レチノマックスによる自然瞳孔下 の屈折值を収集し統計学的に検討した。また、 その方法とレチノマックス ${ }^{\circledR}$ 健診現場で使用す る際の注意点について検討した。

\section{III. 結 果}

福島市では 3 歳児健診に視能訓練士 2 名が参
加し全受診児にレチノマックスを用いた屈折検 查を行い、必要に応じて視力、眼位、立体視の 検査を行っている。実施時期は 3 歳 6 力月であ る。

平成15年度から18年度の、福島市の 3 歳児健 診該当者は 11,267 人で、受診者は 10,639 人、受診 率は94.43\%であった。その受診児のうち 10,454 人にレチノマックス ${ }^{\circledR} に よ る$ 両眼の屈折検査が可 能であり、検査可能率は98.26\%であった。検査 が施行できなかった理由は、児が怖がった、泣 いてしまったなどであった。

等価球面值の平均值 \pm 標準偏差は $-0.97 \pm$ $1.15 \mathrm{D}$ であったが、正規分布ではなく、最頻值 はー0.875Dで遠視側に急峻で、近視側により平 坦な分布を示した（図 $1 \mathrm{a} ）$ 。中央值は -0.875 D、四分位範囲は $-1.5 〜-0.375 \mathrm{D}$ であった（図 $2 \mathrm{a} ） 。$ 遠視に測定されていたものが 2,424 眼 $(11.59 \%) 、+2$ D以上の遠視は159眼（0.76\%)、 a

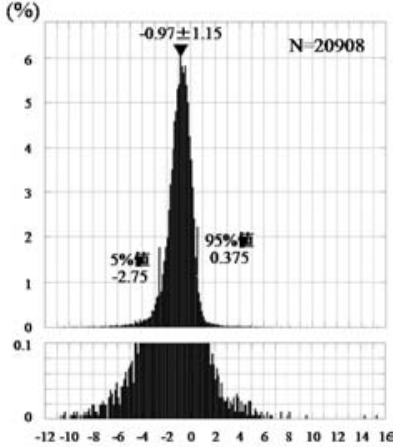

等価球面屈折䛧(D)

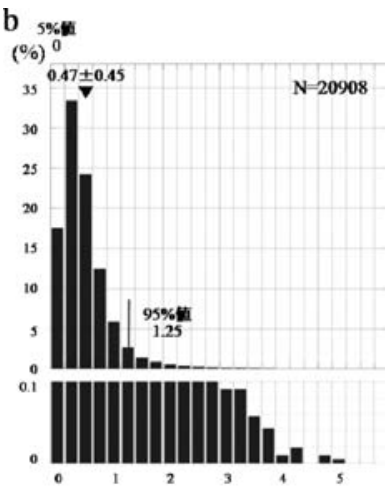

円柱屈折䛧(D)

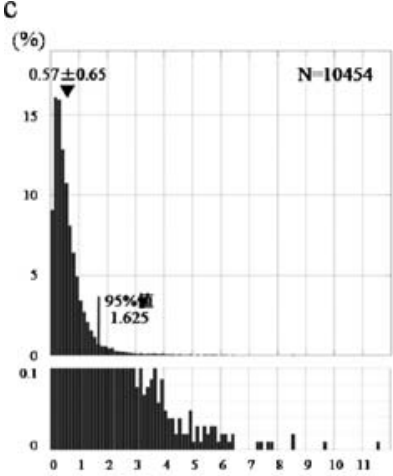

球面屈折䛧左右差(D)

図 1 屈折值分布ヒストグラム. $\mathrm{a}$ ：等価球面屈折值， b : 円柱屈折值， $\mathrm{c}$ ：等価球面屈折值左右差, : 平均值 \pm 標準偏差

a

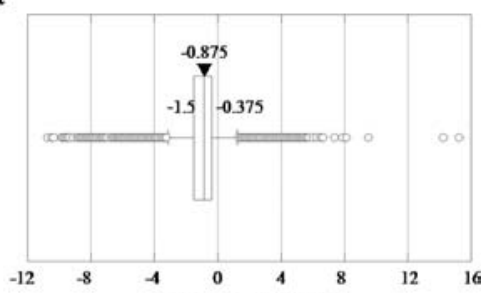

等価球面羞折优(D) b

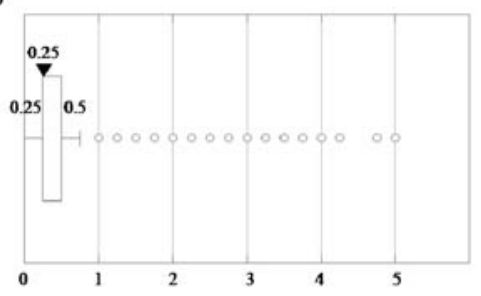

円柱帱折值(D)
C

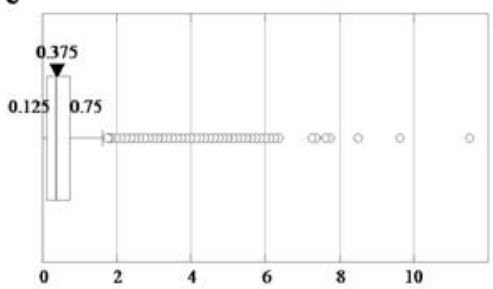

㖤折値左右差(D)

図 2 屈折值分布箱髭図

$\mathrm{a}$ ：等価球面屈折值， b : 円柱屈折值， $\mathrm{c}$ ：等価球面屈折值左右差,

$\boldsymbol{\nabla}$ : 中央値，四角：四分位範囲 
+ 4 D以上の遠視は51眼（0.24\%）であった。ま た、弱主経線球面屈折值は $-0.74 \pm 1.16 \mathrm{D}$ であっ た。

円柱屈折値の平均值 \pm 標準偏差は $0.47 \pm 0.45 \mathrm{D}$ で、最頻值は $0.25 \mathrm{D} 、 中$ 央值は $0.25 \mathrm{D}$ 、四分位範 囲は0.25〜0.5Dであった（図 $1 \mathrm{~b}$ ，図 $2 \mathrm{~b}$ ）。1.5D 以上の乱視は 818 眼 $(3.91 \%) 、 2$ D以上の乱視は 343眼（1.64\%）であった。

10,454 人の球面屈折値左右差の平均值 \pm 標準

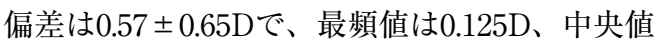

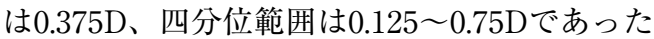
（図 $1 \mathrm{c}$, 図 $2 \mathrm{c}$ )。左右差 $1 \mathrm{D}$ 以上は 1,675 人 (16.02\%)、1.5D以上は657人 (6.28\%)、2 D以上 は347人（3.32\%）であった。

\section{IV. 考按}

3 歳児の屈折値について、神田らは1,330眼を 対象とした同一検者による検影法での弱主経線

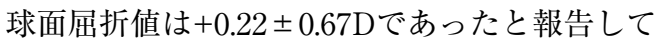
いる ${ }^{10)}$ 。今回のレチノマックス ${ }^{\circledR}$ での弱主経線球

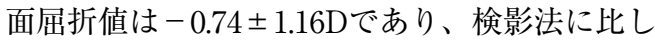
てレチノマックス ${ }^{\circledR}$ での測定值は約 1 Dほど近視 の結果であった。従来から指摘されているよう に、レチノマックスによる測定では調節の介入 が避けられない(11,13) 15) と考えられた。

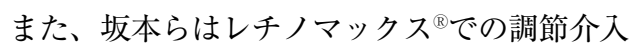
は遠視眼で大きく、近視眼で小さい傾向があっ
たと報告している ${ }^{11)}$ 。今回の等価球面值の分布 が遠視側でより急峻、近視側でより平坦な非対 称であったことは、遠視眼の多くが調節の介入 により土0 D付近に収束していたものと考えら れた。

今回の 3 歳児の球面屈折值左右差は $0.57 \pm$ $0.65 \mathrm{D}$ であり、 $2 \mathrm{D}$ 以上の不同視は全体の $3.32 \%$ にみられた。野原らの両眼開放ポータブルレフ FR-5000 ${ }^{\circledR}$ 用いた 3 歳児の屈折值の報告では等 価球面值の左右差の平均は $0.29 \pm 0.32 \mathrm{D}$ とあり ${ }^{1}$ 、 また、 $2 \mathrm{D}$ 以上の不同視の割合については、神 田らは検影法にて $0.6 \%{ }^{10)}$ 、玉城らは据え置きレ フRK- $1^{\circledR} に て 2.6 \%{ }^{12)}$ と報告している。今回のレ チノマックスによる結果は、過去の報告より屈 折值の左右差が大きく、不同視の割合も多いも のとなった。実際にレチノマックス㳊用した 経験から、測定開始眼はより近視側な值から始 まり、かつ屈折值が不安定なことが多い。器械 の接近により発生した調節の残存により屈折值 の左右差が過大に検出された可能性があると推 測された。

2 D以上の乱視については、野原らは $0.37 \%$ 1)、神田らは $1.4 \%^{10)}$ 、玉城らは $1.8 \% \%^{12)}$ と報告し ており、今回もほぼ同等の結果であったが、光 軸からずれると乱視の測定值が不正確になるた め、携帯型の場合は特に正面から誢き込む注意 が必要である。

調節力の強い幼児の屈折検査には、固視目標

表 1 各種屈折検查の長所と短所

\begin{tabular}{|c|c|c|c|c|c|c|c|}
\hline & & スペース & 調節除去効果 & 恐怖感 & 検査時間 & 携帯性 & 操作性 \\
\hline \multirow{2}{*}{ 携帯型 } & 内部視標 & () & $x$ & $\triangle$ & () & () & 0 \\
\hline & 外部固視 & $x$ & O & $\bigcirc$ & $\triangle$ & 0 & $\triangle$ \\
\hline 据え置き & 内部視標 & $\triangle$ & $\triangle$ & $x$ & 0 & $x$ & (0) \\
\hline 型 & 外部固視 & $x$ & 0 & $\triangle$ & $\bigcirc$ & $x$ & $\bigcirc$ \\
\hline \multicolumn{2}{|c|}{ 検影法 } & $\triangle$ & () & 0 & $\triangle$ & (a) & $x$ \\
\hline
\end{tabular}

○：優れる $\bigcirc$ : やや優れる $\triangle$ : やや劣る $\times$ : 劣る 
が遠方であることや十分な雲霧がかかる機器の 使用が望ましいが、健診現場では様々な屈折検 査機器が用いられており、それぞれに長所と短 所とが報告されている(1) 3), 5), 6),13) 15)（表 1 ）。調 節が介入しにくいことから小児の屈折検査には 検影法が最も望ましいとされているが13)、健診 で短時間に多くの児の検査を行うには検者の習 熟を要し、現実的ではない。

それに対して、レチノマックス ${ }^{\circledR}$ は携帯型で 内部視標であり、機械そのものが近づくことに より、調節介入が大きくなるとされている $\left.{ }^{13)} \sim 15\right) 。$ しかし、小型軽量で携帯性があり、検査場所の 制限がないため多数箇所での健診に対応でき、 また、操作が容易で所要時間が短く、検査可能 率が高いメリットがある ${ }^{13)}$ 。したがって、今後 屈折検査を導入する自治体で同機種が選択され ることも考えられるが、実際の使用に当たって は、できるだけ調節を介入させない工夫が必要 と思われる。そこで、福島市の 3 歳児健診にお けるレチノマックス ${ }^{\circledR}$ の使用時には、(1)「遠くの 方にも何か見えるかな」などと、「しっかり見 て」とは言わず、内部視標を凝視しないように 声掛けをすること、(2) 内部モニターで測定值や 瞳孔を確認しながら測定し、変動する際は、值 が一定するまで待つこと、(3) 屈折值の左右差が 大きい場合は、左右眼を繰り返し測定して確認 すること、(4) 軽度の屈折異常の場合には、視力 と照合することが必要であること、などに注意 して屈折検査を行っている。

以上により、3 歳児健診でのレチノマックス ${ }^{\circledR}$ による屈折検査は、検査可能率が高く、健診現 場での使用には有用である。しかし、検影法に 比し $1 \mathrm{D}$ 程度の調節の介入があるとともに、当 然個々で調節介入にバラつきがあることから、 それのみで視力に代わるスクリーニング検査に はなりえない。したがって、視力值と照合して 結果を判断すれば、その効果を十分発揮するも のと考えられた。

\section{参考文献}

1 ）野原雅彦，高橋まゆみ：3 歳巟健康診査にお ける屈折検查の 6 年間の結果. 眼臨 99 ：
$227-230,2005$.

2）長尾長彦, 光田志のぶ, 高崎裕子, 渡辺好 政：倉敷市における 3 歳児健康診査での視覚 検査の現状. 日視会誌 33：113-117, 2004.

3) 内海 隆 : 三歳児健診の屈折検査について. 眼臨 $101: 22-25,2007$.

4）磯部真理子, 黒田紀子, 今永絵美, 関 公, 千葉弥幸：千葉県に扮ける三歳児健診の結果 と問題点. 眼臨 $91: 450-454,1997$.

5）川端清司：フォトレフラクトメーターによる 3 歳児健診あづみ野眼科 8 年間のまとめ. 眼 臨 98:959-962, 2004.

6）稲泉令巳子，平尾真実，中村桂子，澤ふみ子, 濱村美恵子, 清水みはる, 他：高柣市におけ る 3 歳児眼科健診の現状. 眼臨 $99 ： 223-$ 226, 2005.

7）社会法人日本視能訓練士協会健診業務委員 会: 三歳児眼科健診マニュアル (第一版). J.A.C.O.NEWS 第112号

8）中村桂子, 丹治弘子, 恒川幹子, 猿谷淳子, 長尾長彦：三歳児眼科健診の現状. 眼臨 $101: 85-90,2007$.

9）橋本禎子：三歳児健診の地域格差. 眼臨 $101: 17-21,2007$.

10）神田孝子, 川端芳克, 山口直子, 内田尚子： 3 歳児の屈折分布について. 眼臨 $80 ： 299$ 302, 1986.

11）坂本章子, 吉永宏美, 関向秀樹, 丹治弘子, 橋本禎子，八子恵子：三歳児眼科検診におけ る手持ち式オートレフラクトメーター（レチ ノマックス $\left.{ }^{\circledR}\right)$ の有效性. 眼臨 $95: 478-481$, 2003.

12）玉城宏一，千葉奈緒子，川村 緑，矢沢興司， 加藤和男：幼児の屈折分布について - 自動屈 折検查器を使用してー。 眼臨84：615-618, 1990.

13）稲泉令巳子, 内海 隆, 中村桂子, 菅澤淳, 澤ふみ子, 寺本美恵子, 他：小児の眼科スク リーニングにおけるレチノマックス ${ }^{\circledR}$ の評価. 眼臨 $92: 722-724 ， 1998$.

14）恒川幹子, 林 浩実, 梅沢直美, 内田英哉, 水谷 聡: 幼児眼科検診におけるレチノマッ クス ${ }^{\circledR}$ FR-5000 ${ }^{\circledR}$ の比較. 眼臨 $93 ： 1064-$ 
1067, 1999.

15）田中千春，西村 晋： 3 歳児健診における 種々のタイプのオートレフの使用経験. 眼臨 $91: 447-449,1997$.

16）佐藤栄一, 今野 優, 長岡泰司, 花田一臣, 吉田晃敏：眼科検診における手持ち式オート
レフラクトメーターの有効性. 眼臨 94 ： $862-864,2000$.

17）加宅田匡子, 丹治弘子, 佐藤広尚, 橋本禎子, 八子恵子, 加藤桂一郎 : ポータブルレフGRM3の使用経験. 眼臨 88：941-943，1994. 